\title{
Monika Bielińska (red.), 2020: Leksykografia. Słownik specjalisty- czny, Kraków: TAiWPN UNIVERSITAS, 478 s., ISBN 978-83-242- 3670-1.
}

DOI: https://doi.org/10.19195/0137-1169.40.10

„Leksykografia. Słownik specjalistyczny” pod redakcją Moniki Bielińskiej wydany w 2020 roku w Krakowie jest owocem współpracy zespołu autorów haseł: Moniki Bielińskiej, Aleksandry Chrupały, Agnieszki Frączek, Marka Gładysza, Barbary Komendy-Earle, Aleksandry Łyp-Bieleckiej, Anny Martowicz, Mirosławy Podhajeckiej i Włodzimierza Wysoczańskiego. Omawiana pozycja jest próbą przedstawienia najważniejszych pojęć z zakresu leksykografii, a tym samym pierwszym opracowaniem tego rodzaju przeznaczonym dla polskojęzycznego odbiorcy, odpowiadającym na zapotrzebowanie na słowniki fachowe $\mathrm{z}$ tego zakresu. W monografii najwięcej uwagi poświęcono leksykografii językowej - celem publikacji jest wyeksponowanie interdyscyplinarnego charakteru tej dziedziny, a szczególnie jej ścisłego związku z językoznawstwem.

W artykule „Status i istota leksykografii. Stanowiska i kontrowersje” przedmiotem rozważań Moniki Bielińskiej jest zróżnicowanie stanowisk, jakie na przestrzeni lat wykształciły się wokół terminu leksykografia. Artykuł poświęcony został praktycznemu i teoretycznemu wymiarowi leksykografii, stosunkowi leksykografii do językoznawstwa oraz stanowisku przedstawiającemu leksykografię jako odrębną dyscyplinę. Autorka zauważa, że podział stanowisk przedstawiających leksykografię jako teorię, praktykę lub ich połączenie jest podziałem uproszczonym. Mylące okazać się może zredukowanie leksykografii do nauki o metodach opracowywania słowników, co tylko nieznacznie odbiega od utożsamiania jej wyłącznie z działaniami praktycznymi. Właściwym wydaje się rozumienie leksykografii jako połączenie komponentu praktycznego i teoretycznego z uwzględnieniem dorobku współczesnej metaleksykografii (Bielińska 2019:115). Bielińska zauważa, że w opracowaniach na temat stosunku leksykografii do językoznawstwa termin leksykografia jest niekiedy redukowany w swoim znaczeniu do leksykografii językowej (Bielińska 2019:115). W omawianym słowniku autorka konsekwentnie rozgranicza leksykografię językową i leksykografię w rozumieniu całościowym. Ponadto w artykule przytoczone zostały argumenty przemawiające za istnieniem powiązań leksykografii językowej z językoznawstwem przy jej równoczesnej dyskwalifikacji jako części językoznawstwa. Bielińska przytacza również stanowiska uznające autonomiczność leksykografii jako dyscypliny. Definiując pojęcie dyscypliny, dochodzi do wniosków, że za dyscyplinę naukową uznana zostać może metaleksykografia, natomiast leksykografia w rozumieniu całościowym jest dyscypliną akademicką (Bielińska 2019:135-136). Rozważania zawarte $\mathrm{w}$ artykule oraz przyjęte przez Bielińską stanowisko na temat natury i statusu leksy- 
kografii korespondują z zarysem problematyki oraz próbą zdefiniowania leksykografii w czwartym rozdziale słownika.

Książka ma przejrzystą strukturę, składa się z dwóch części: wstępnej i hasłowej. Część wstępna zbudowana jest z czterech rozdziałów (1. „Wstęp”, 2. „Budowa artykułu hasłowego”, 3. „Wykazy skrótów”, 4. „Leksykografia. Zarys problematyki”). W rozdziale pierwszym zwrócono uwagę na to, jak niewiele istnieje słowników fachowych z zakresu leksykografii (Bielińska 2020:9). Dalej przedstawiono cel publikacji, wyjaśniając, do jakich tradycji nawiązuje oraz jakiego typu leksykografii poświęca najwięcej uwagi. Znaczna część tego rozdziału przedstawia resztę zawartości monografii - wymienia między innymi rodzaje haseł pojawiających się w słowniku, przedstawia typy omawianych słowników oraz uwzględnia aspekty związane z ich opracowywaniem i użyciem. We „Wstępie” zamieszczono również informacje o bazie materiałowej opracowania - są to publikacje polsko- i obcojęzyczne, to jest artykuły z czasopism i tomów zbiorowych, monografie, podręczniki, kompendia, leksykony, strony internetowe projektów słownikowych, wstępy do słowników (Bielińska 2020:10). Adresatami tej publikacji są leksykografowie, językoznawcy i naukowcy zajmujący się obszarami pokrewnymi, a także osoby, których aktywność zawodowa związana jest $\mathrm{z}$ językiem i pracą $\mathrm{z}$ tekstem.

Rozdział drugi zawiera szczegółowy opis budowy artykułu hasłowego - graficzny układ tekstu nawiązuje do schematu stosowanego w artykułach tekstowych. Komponenty artykułu hasłowego, między innymi wyraz hasłowy, objaśnienie znaczenia, opis uzupełniający, inicjały autora bądź autorów hasła, określenia synonimiczne, pozycja odsyłaczowa czy dane bibliograficzne, ułatwiają czytelnikowi sprawne korzystanie ze słownika.

Rozdział trzeci to wykaz skrótów używanych w hasłach, skrótów nazw słowników stosowanych w hasłach oraz w listach literatury sekundarnej.

Rozdział czwarty jest wprowadzeniem do leksykografii i ogólnym zarysem problematyki. Jest próbą odpowiedzi na pytanie, czym jest leksykografia, odnosi się do literatury przedmiotu (por. m.in. Wiegand 1984, Miodunka 1989, Bańko 2001, Piotrowski 2001), w której prezentowane są zróżnicowane stanowiska na ten temat, od zaliczenia leksykografii do językoznawstwa stosowanego (Bielińska 2019:116) po jej wykluczenie jako działu nauki (Piotrowski 2001:27).

Bielińska ustosunkowuje się do panujących wśród językoznawców przekonań i stwierdza, co następuje: „Leksykografia językowa nie jest częścią językoznawstwa bądź językoznawstwa stosowanego czy leksykologii, a teoria leksykograficzna nie jest tożsama z teorią językoznawczą ani ściślej: leksykologiczną" (Bielińska 2020:19).

W literaturze przedmiotu obecne są także przeciwstawienia leksykografii jako praktyki i jako teorii. Leksykografia definiowana jest jako słownikarstwo, nauka o słownikach bądź nauka łącząca oba te elementy. Na potrzeby recenzowanej publikacji przyjęto, „że leksykografia obejmuje opracowywanie słowników wszelkiego rodzaju oraz naukę o nich, czyli metaleksykografię" (Bielińska 2020:17).

W rozdziale czwartym sporo uwagi poświęcono również powiązaniu leksykografii $\mathrm{z}$ innymi dyscyplinami naukowymi, przedstawione zostały ponadto zadania metaleksykografii. Część rozdziału poświęcona została historii kształtowania się leksykografii językowej z uwzględnieniem najważniejszych dzieł na przestrzeni wieków. W opisie uwzględniono również poszczególne etapy rozwoju leksykografii, a także zmianę postrzegania jej roli, co finalnie umożliwiło charakterystykę współczesnej leksykografii. Rozważania na temat istoty leksykografii, przedstawienie historii jej rozwoju, a także zasygnalizowanie 
istnienia różnych stanowisk obecnych w literaturze przedmiotu pozwala czytelnikowi zrozumieć motywację i cel powstania recenzowanej publikacji.

Część hasłowa obejmuje 693 hasła, w tym 355 haseł samodzielnych i 338 odsyłaczowych. Każdy artykuł hasłowy zawiera: wyraz hasłowy, objaśnienie znaczenia, opis uzupełniający oraz inicjały autora bądź autorów hasła. Pozostałe elementy, takie jak określenia synonimiczne, pozycja odsyłaczowa, dane bibliograficzne słowników oraz wykaz literatury sekundarnej, są fakultatywne i nie występują we wszystkich hasłach. Pierwszy akapit każdego artykułu hasłowego stanowi zwięzłe przedstawienie danego pojęcia, następnie hasło rozszerzane jest o opis uzupełniający, zwykle obszerniejszy od objaśnienia znaczenia.

Omawiana publikacja jest ważną pozycją na liście opracowań z zakresu leksykografii. Zarys problematyki oraz rozważania na temat jej istoty dają odpowiedź na postawione w rozdziale czwartym pytania i stanowią ważny wkład w naukową dyskusję na ten temat. Próba przedstawienia najważniejszych pojęć leksykograficznych jest próbą udaną. Klarowny podział dzieła na części i rozdziały oraz układ graficzny tekstu w przypadku artykułów hasłowych w dużej mierze ułatwiają korzystanie ze słownika. „Leksykografia. Słownik specjalistyczny” skutecznie wypełnia lukę istniejącą w tym obszarze badawczym i jest pozycją godną polecenia językoznawcom, leksykografom oraz naukowcom zajmującym się gałęziami pokrewnymi. Warto zwrócić uwagę na innowacyjność tej publikacji: wybrane hasła obejmują również takie pojęcia, które w języku polskim nie mają jeszcze utrwalonych nazw. Autorzy proponują zatem własne określenia, które celem rozróżnienia od tych rozpowszechnionych oznaczono znakiem + w indeksie górnym, co wskazuje na pilną potrzebę dalszych rozważań, analiz i porównań w tej dziedzinie.

\section{Bibliografia}

BAŃKo Mirosław, 2001, Z pogranicza leksykografii i językoznawstwa, Warszawa.

BielińsKa Monika, 2019, Status i istota leksykografii. Stanowiska i kontrowersje, w: Polonica 39 (1), s. 111-148.

Miodunka Władysław, 1989, Podstawy leksykologii i leksykografii, Warszawa.

Piotrowski Tadeusz, 2001, Zrozumieć leksykografię, Warszawa.

WiEgand Herbert Ernst, 1984, On the structure and contents of a general theory of lexicography, w: Hartmann R.R.K. (red.), LEXeter '83 Proceedings. Papers from the International Conference on Lexicography at Exeters, s. 13-30.

Aleksandra Molenda ORCID: 0000-0001-9309-9289 Uniwersytet Wrocławski, Polska 